\title{
Critical Limits of Phosphorus in Soil and Pea Plant Grown in Acid Soils of Senapati District of Manipur, India
}

\author{
Haribhushan Athokpam ${ }^{1 *}$, Goutam Kumar Ghosh ${ }^{2}$, Herojit Singh Athokpam ${ }^{3}$, \\ N. Anando Singh ${ }^{4}$, Kangjam Sonamani Singh ${ }^{5}$, Khamrang Mathukmi ${ }^{6}$, R.S. Telem ${ }^{7}$, \\ Romila Akoijam ${ }^{8}$, Shabir Hussain Wani ${ }^{9}$, Nandini Chongtham ${ }^{10}$ and \\ Naorem Brajendra Singh $^{3}$
}

${ }^{1}$ Krishi Vigyan Kendra (Farm Science Centre), South Garo Hills-794108, Meghalaya, India

${ }^{2}$ Visva-Bharati University, Soil Science and Agricultural Chemistry, Sriniketan - 731236 ,

West Bengal, India

${ }^{3}$ Central Agricultural University, College of Agriculture, Iroisemba, Imphal, 795004, Manipur, India

${ }^{4}$ AICRP on Chickpea, Directorate of Research, Central Agricultural University, Imphal, Manipur (795 004), India

${ }^{5}$ Krishi Vigyan Kendra (Farm Science Centre), Chandel District, P.O. Chandel, Manipur - 795127, India

${ }^{6}$ Ethno Medicinal Research Centre, P.O. Kangpokpi - 795129, Manipur - India

${ }^{7}$ Krishi Vigyan Kendra (Farm Science Centre), Senapati District, P.O. Kangpokpi - 795129, Manipur- India

${ }^{8}$ ICAR-Research Complex for NEH Region, Manipur Centre-795 004, India

${ }^{9}$ Mountain Research Centre for Field Crops, Khudwani Anantnag-192101, Sher-e-Kashmir

University of Agricultural Sciences and Technology of Kashmir, J\&K, India

${ }^{10} \mathrm{KVK}$, CAU, Imphal, Farm Science Centre, Andro, Imphal East-795149, Imphal, India

*Corresponding author

\section{A B S T R A C T}

\section{Keywords}

Phosphorus, Critical limit, Acidic, Soil, Pea

Article Info

Accepted:

20 August 2018

Available Online:

10 September 2018
A pot culture study was conducted in 20 acidic soils of Senapati District of Manipur, India during rabi season of 2013-14 to estimate the critical limit of $\mathrm{P}$ in soil and pea plant for predicting the response of pea (Pisum sativum L.) to $\mathrm{P}$ application as well as to study the effect of $\mathrm{P}$ application on dry matter yield and uptake of nutrients in pea crop. The experimental soil was acidic in nature, electrical conductivity of the soil was in safe limit for crop growth. The organic carbon status was almost high and soil was clay in textural class. Pot culture studied showed that the application of phosphorus@60 kg $\mathrm{P}_{2} \mathrm{O}_{5}$ ha $^{-1}$ significantly superior $(85 \%)$ of the studied soils to any other treatments and $40 \mathrm{~kg} \mathrm{P}_{2} \mathrm{O}_{5}$ ha $^{-1}$ was significantly $(15 \%)$ to the total soils in dry matter yield of Pea variety Arkel. The critical limit of the $\mathrm{P}$ concentration in the pea was found 0.42 per cent. It was revealed that the critical level of phosphorus in the soils for growing of pea plants varied with the methods of phosphorus extraction. The critical level of soils ranged from 14.30 to $25 \mathrm{~kg} \mathrm{P}_{2} \mathrm{O}_{5}$ ha $^{-1}$ depending upon the methods of phosphorus extraction. 


\section{Introduction}

Phosphorus is the second most important plant nutrient after nitrogen for agricultural production in most regions of the world. Unlike nitrogen, whose supply from atmosphere is limited by natural cycling, it is recycled in negligible quantities. Phosphorous is one of the major plant nutrients that directly or indirectly affect all plant physiological processes. It is the key component of energy metabolism and synthesis of nucleic acids and membranes as well as atmospheric nitrogen fixation in the leguminous crops.

Phosphorous enhances many aspects of plant physiology, including the fundamental processes of photosynthesis, nitrogen fixation, flowering, fruiting (including seed production), and maturation. Phosphorus has a key role in the energy metabolism of all plant cells and particularly for nitrogen fixation in legume crops. Pea requires a relatively high phosphorus nutrition (Slinkard and Drew, 1988) and phosphorus fertilization and phosphorus fertilization enhances yield and seed quality (Pulung, 1994). In spite of its importance in biology, plant strive hard to obtain this essential nutrient from the crop rhizosphere. Phosphorus deficiency is considered to be one of the major limitations for crop production, particularly in the lowinput agricultural systems around the world. P-deficient plants often seem quite normal in appearance. In severe cases, $\mathrm{P}$ deficiency can cause yellowing and senescence of leaves. In many acidic soils in developing countries, $\mathrm{P}$ deficiency is the main limiting factor for crop production and, therefore, requires the application of $\mathrm{P}$ fertilizers for optimum plant growth and production of food and fibre (Attar, 2014). Phosphorus is known to play an important role in growth and development of the crop and have direct relation with root proliferations, straw strength, grain formation, crop maturation (Bhat et al., 2013).
Although $\mathrm{P}$ is abundant in soils in both organic and inorganic forms (Khan et al., 2009), the amount of available forms to plants is generally low, because the majority of soil $\mathrm{P}$ is found in insoluble forms, while the plants absorb it only in soluble ions $\left(\mathrm{H}_{2} \mathrm{PO}_{4}\right.$ - and $\mathrm{HPO}_{4}{ }^{2-}$ ) (Bhattacharyya and Jha, 2012).

The North-East Region of India has geographical area of 26.3 million hectares and almost $85 \%$ of the soils are moderate to strongly acidic (Das et al., 2016). Phosphorus deficiency is the main limiting factor for crop production in acidic soils and therefore, requires the application of phosphatic fertilizers for optimum plant growth and production of food and fibre (Attar, 2014). Nutrient deficiency of plant can be replenished well in advance before heavy loss. Therefore, the present investigation was planned to study the critical level of phosphorous on the soils and plants and response of phosphorus fertilization for optimum pea production, grown in acidic soils.

\section{Materials and Method}

The pot culture experiment was conducted during the rabi season of 2013-14 at Krishi Vigyan Kendra- Senapati, Manipur, India with objective to establish critical limit of P in soil and for pea crop as well as to study the effect of $\mathrm{P}$ application on dry matter yield and uptake of nutrients in pea crop. The geographical area of the district is $3271 \mathrm{sq} . \mathrm{km}$ with $14.56 \%$ of the total geographical area of the state. The average temperature ranges from $4^{\circ} \mathrm{C}$ to $32^{\circ} \mathrm{C}$ and average annual rainfall varies from 671 to $1454 \mathrm{~mm}$. It is located between $24^{\circ} 30^{\prime} \mathrm{N}$ latitude and $93^{\circ} 30^{\prime} \mathrm{E}$ longitude over the globe. The altitude of the district ranges from 800 to $4000 \mathrm{~m}$ above MSL. Senapati district has alluvium, lateritic black regur and ferruginous type of soil (Anonymous, 2009). Twenty soil samples in bulk from plough layer $(0-20 \mathrm{~cm})$ were 
collected from different places of Senapati District of Manipur, India and the processed samples $(<2 \mathrm{~mm})$ were analysed for their physico-chemical characteristics using the standard procedure (Jackson, 1973) and reported in Table 1. 2.5 kilogram of soil was filled in pots and phosphorus was applied at 0 , 40 and $60 \mathrm{~kg} \mathrm{P}_{2} \mathrm{O}_{5}$ ha $^{-1}$ through single super phosphate. Similar procedure has also been used by Mahajan et al., 2013 in Wheat. The treatments were replicated thrice in a completely randomized design. A basal application of 30: $40 \mathrm{~N}: \mathrm{K}_{2} \mathrm{O}$ ha $^{-1}$ was applied in the form of urea and MOP in each pot. Pea (Arkel) seeds were sown and thinning was done ten days after sowing keeping four healthy plants in each pot. The crop was harvested 40 days after germination. The plant samples were washed in water and dried in oven at $65^{\circ} \mathrm{C}$ for $48 \mathrm{hr}$ and the dry matter yield was recorded. The samples were then powdered and requisite quantities of the same were digested in nitricperchlororic acid mixture. Mechanical analysis of various soil samples for its sand, silt and clay fractions was carried out by N.B.S.S and LUP using hydrometer methods described by Buoyoucous (1962). Soil pH was determined by glass electrode systronic $\mathrm{pH}$ meter in 1.2.5 soil-water suspension method (Jackson, 1973). Organic carbon was determined by wet oxidation method of Walkley and Black (Jackson, 1973). The cation exchange capacity was determined by leaching the soil with $1 \mathrm{~N}$ $\mathrm{NH}_{4}^{+} \mathrm{OAC}$ (ph 7.0) suggested by Borah et al., (1987). Phosphorus was determined by using Vanadomolybdophosphoric acid reagent. To test the suitability, six test methods were used (Table 2). The soil samples were shaken for two minutes with soil to solution ratio of 1:10. Extractable phosphorus was determined Spectrophotometrically.

An attempt was made to find out the critical level of phosphorous on the soils and plants in accordance with the procedure of Cate and
Nelson (1965) using a scatter graphical approach, partitioning the two dimensional percentage yields versus soil test levels and phosphorus concentration in the pea plants (control) scattered into two groups.

\section{Bray's percent yield}

Bray's percent yield of pea for each soil samples was calculated by using the relationship

Yield without fertilizer

Bray's percent yield = X 100

Maximum yield in fertilizer treated pots

\section{Bray's percent uptake}

Bray's percent uptake of pea was calculated as:

Uptake without fertilizers

Bray's percent uptake $=$ X 100

Maximum uptake in fertilizer treated pot

Simple correlation analysis was carried out to establish the relationships between the $\mathrm{Zn}$ and soil properties.

\section{Results and Discussion}

\section{Soils properties}

The data of initial physical and chemical properties of soils of Senapati District of Manipur are presented in table 1. From data it was seen that soil texture varied from clay, clay loam and silty clay in the textured class. The percent of studied soils was clay. The soils had $\mathrm{pH}$ values ranging from 4.50 to 5.62. All the investigation soil samples were acidic in nature with a mean value of soil reaction 5.15. The organic carbon status of soil samples ranged from $13.40 \mathrm{~g} \mathrm{~kg}^{-1}$ to $24.00 \mathrm{~g}$ $\mathrm{kg}^{-1}$ with a mean value of $20.35 \mathrm{~g} \mathrm{~kg}^{-1}$. In general, soils were high in organic carbon 
content. The CEC of the soils ranged from $11.40\left[\mathrm{Cmol}\left(\mathrm{p}+\mathrm{kg}^{-1}\right]\right.$ to 28.20 with a mean value of $17.81\left[\mathrm{Cmol}(\mathrm{p}+) \mathrm{kg}^{-1}\right]$. The total nitrogen present in the soils ranged from 0.09 to 0.22 percent with a mean value of 0.14 percent. The available nitrogen content of the soil samples collected from different locations ranged from $208.70 \mathrm{~kg} \mathrm{ha}^{-1}$ to $423.25 \mathrm{~kg} \mathrm{ha}^{-1}$ i.e. low to medium available nitrogen content in the study soils. The average of available nitrogen in these soils was $335.14 \mathrm{~kg} \mathrm{ha}^{-1}$.

The soils had $\mathrm{P}$ values ranging from $18 \mathrm{~kg} \mathrm{ha}^{-1}$ to $64 \mathrm{~kg} \mathrm{ha}^{-1}$ with a mean value of $39.40 \mathrm{~kg}$ $\mathrm{ha}^{-1}$. The available potassium present in these soils varied from $90.34 \mathrm{~kg} \mathrm{ha}^{-1}$ to $243.10 \mathrm{~kg}$ $\mathrm{ha}^{-1}$ with a mean value of $151.90 \mathrm{~kg} \mathrm{ha}^{-1}$. Out of the 20 samples collected from various locations, 15 percent \& 85 percent were low and medium potash content in the soils, respectively.

\section{Effect of phosphorus on dry matter yield}

The data presented in table 3 revealed that the dry matter yield of pea was greatly influenced by different levels of phosphorus concentration. The dry matter yield in the control varied from $1.08 \mathrm{~g} / \mathrm{pot}$ to $2.89 \mathrm{~g} / \mathrm{pot}$ as compared with $1.86 \mathrm{~g} /$ pot to $3.55 \mathrm{~g} / \mathrm{pot}$ in 40 $\mathrm{Kg} \mathrm{P}_{2} \mathrm{O}_{5}$ ha $^{-1}$ and $2.32 \mathrm{~g} /$ pot to $4.35 \mathrm{~g} /$ pot in $60 \mathrm{Kg} \mathrm{P}_{2} \mathrm{O}_{5} \mathrm{ha}^{-1}$, respectively. An application of phosphorus increased the dry matter yield of pea regardless of its initial phosphorus status of all the soil samples collected from various locations. Similar results of phosphorus on dry matter yield of pea were also reported by Bhalu et al., (1995) and Hussain et al., (2001). Dry matter yield varied with the soils collected from different locations depending upon their physicochemical properties. Significant difference of dry matter yield of pea was observed among the different soil samples and their interactions with the different levels of phosphorus treatment. The increased dry matter yield due to phosphorus application may probably be increased plant height, number of branches, and number of leaves and the leaf area of the plants and also possibly accelerated the nitrogen fixing power of the plant by increasing activity of nodule bacteria which could lead to more dry matter accumulation.

The dry matter yield of pea due to different treatments of phosphorus was significant at 0.05 level of probability. On the other hand, the dry matter yield of different soils collected from various locations and interaction between different soils and phosphorus treatments was also found significant at 0.01 and 0.05 level of probability.

\section{Effect of phosphorus on nitrogen, phosphorus and potassium uptake}

\section{Nitrogen uptake}

It was evident from the table that nitrogen uptake by pea plant was highest with phosphorus applied @ 60 kg $\mathrm{P}_{2} \mathrm{O}_{5} \mathrm{ha}^{-1}$ (39.08 $\mathrm{mg} / \mathrm{pot}$ ) which was significantly superior to any other treatments. Irrespective of the initial soil properties, an application of phophatic fertilizer increased the nitrogen uptake by the plants (Table 4). The uptake of nitrogen by the plant is the combined effect of higher nitrogen content in the plants as well as total dry matter yield. On the other hand, various soils collected from different places also influenced the nitrogen uptake by the plants. Similar observation was also reported by Bhalu et al., (1995). A profuse vegetative growth and higher dry matter accumulation due to application of phosphorus might increase nitrogen uptake by pea plants

\section{Phosphorus uptake}

It was evident from the table that phosphorus uptake by pea plant was highest with phosphorus applied @ 60 kg $\mathrm{P}_{2} \mathrm{O}_{5} \mathrm{ha}^{-1}$ (18.23 
$\mathrm{mg} / \mathrm{pot}$ ) which was significantly superior to the other treatments. The significant increase of phosphorus uptake by the pea plants was effect of higher dry matter accumulation due to phosphorus application as well as increase phosphorus content in the plants. There was consistent increase in phosphorus uptake with increasing levels of phosphorus rate by the pea plants. This increased uptake of phosphorus with phosphorus levels might owe to release of more phosphorus and better utilization with phosphorus application by pea plants. This confirms the finding of Reddy et al., (1990) and Bhalu et al., (1995).

\section{Potassium uptake}

It was evident from the table that the amount of potassium uptake was lower than that of nitrogen but higher than phosphorus uptake by the pea plants. However, the pattern of uptake was more or less the same in all the cases (Table 4). It was evident that the potassium uptake by the pea plants increased with the increasing levels of phosphorus application. Similar result was also reported by Reddy et al., (1990) and Bhalu et al., (1995). The highest potassium uptake was found with the application of $60 \mathrm{~kg} \mathrm{P}_{2} \mathrm{O}_{5} \mathrm{ha}^{-1}$ by the pea plants (36.24 mg/pot) which were significantly superior to other treatments. Significant increase of potassium uptake by the pea plants was the cumulative effect of higher dry matter yield and higher potassium in the plants due to different levels of phosphorus application.

\section{Correlation studies with plant parameters}

\section{Bray's per cent yield and uptake}

The data (Table 5) revealed that all the extractants showed positive and significant correlation with Bray's per cent and uptake of pea except Olsen and Mehlich 1. Bray's per cent yield and uptake range from 35.88 to 97.93 per cent and 19.42 to 85.36 per cent respectively (Table 3). Among the extractant used for this investigation, Bray 1 showed higher degree of co-efficient of correlation with Bray's per cent uptake with ' $r$ ' values of $0.699 * *$ than other extractant.

\section{Dry matter yield (control)}

Dry matter yield of pea in the control pot showed the highest significant correlation (Table 5) with Bray $1\left(\mathrm{r}=0.636^{* *}\right)$ which was followed by Mehlich $3\left(\mathrm{r}=0.493^{*}\right)$. The result suggested that the dry matter accumulation by the plants was more or less influence by phosphorus as indicated by high correlation co-efficient with Bray 1.

\section{Phosphorus uptake (control)}

Phosphorus uptake by pea showed significant and positive relationship with available phosphorus as extracted by Bray 1, Bray 2 and Mehlich 3 (Table 5). The result indicated that phosphorus uptake of the control plants had highest and significant positive relationship with Bray 1 extractant ( $\mathrm{r}=0.773 * *)$ which was followed by Bray 2 extractant $\left(\mathrm{r}=0.535^{*}\right)$.

\section{Critical level of phosphorus}

\section{Soils}

It was revealed that the critical level of phosphorus in the soils for growing of pea plants varied with the methods of phosphorus extraction. According to graphical procedure of Cate and Nelson (1965), the critical level of soils ranged from 16.70 to $25 \mathrm{~kg} \mathrm{P}_{2} \mathrm{O}_{5} \mathrm{ha}^{-1}$ depending upon the methods of phosphorus extraction. Bray 1 extractant showed highest degree of correlation with Bray's per cent yield and uptake than the other. Among the extractant Bray 1 (16.70 kg $\mathrm{P}_{2} \mathrm{O}_{5} \mathrm{ha}^{-1}$, Fig. 1) is the most suitable method for assessing critical level as high degree of correlation with Bray's per cent yield and uptake. 
Table.1 Initial physical and chemical characteristics of the experimental soils for the pot study

\begin{tabular}{|c|c|c|c|c|c|c|c|c|c|c|c|c|c|}
\hline \multirow{2}{*}{$\begin{array}{l}\text { SL. } \\
\text { No. }\end{array}$} & \multirow{2}{*}{$\begin{array}{l}\text { Locations/ } \\
\text { Village }\end{array}$} & \multicolumn{11}{|c|}{ Soil characteristic } & \multirow{2}{*}{$\begin{array}{c}\text { Tectural } \\
\text { Class }\end{array}$} \\
\hline & & $\mathrm{pH}$ & $\begin{array}{l}\text { Organic carbon } \\
\quad\left(\mathrm{g} \mathrm{kg}^{-1}\right)\end{array}$ & $\begin{array}{c}\text { Total N } \\
(\%)\end{array}$ & $\begin{array}{l}\text { Available N } \\
\left(\mathrm{kg} \mathrm{ha}^{-1}\right)\end{array}$ & $\begin{array}{c}\text { Available } \\
\mathrm{P}_{2} \mathrm{O}_{5} \\
\left(\mathrm{~kg} \mathrm{ha}^{-1}\right)\end{array}$ & $\begin{array}{c}\text { Available } \\
\mathrm{K}_{2} \mathrm{O} \\
\left(\mathrm{kg} \mathrm{ha}^{-1}\right)\end{array}$ & $\begin{array}{c}\mathrm{Ca}[\mathrm{Cmol}(\mathrm{p}+) \\
\left.\mathrm{kg}^{-1}\right]\end{array}$ & $\underset{\left.\mathrm{kg}^{-1}\right]}{\mathrm{Mg}[\mathrm{Cmol}(\mathrm{p}+)}$ & Clay (\%) & $\begin{array}{l}\text { Silt } \\
(\%)\end{array}$ & Sand $(\%)$ & \\
\hline 1. & Hengbung & 5.00 & 19.00 & 0.14 & 356.12 & 38.40 & 119.00 & 2.20 & 1.30 & 48.80 & 40.10 & 11.10 & Silty clay \\
\hline 2. & Mayangkhang & 5.40 & 21.22 & 0.13 & 338.51 & 42.44 & 90.34 & 3.00 & 1.50 & 56.90 & 33.00 & 9.10 & Clay \\
\hline 3. & T. Khullen & 4.50 & 23.00 & 0.22 & 278.41 & 18.00 & 243.10 & 2.60 & 1.40 & 63.50 & 20.70 & 15.80 & Clay \\
\hline 4. & Ningthoupham & 5.22 & 19.00 & 0.12 & 345.25 & 44.00 & 186.17 & 2.75 & 3.20 & 53.97 & 34.93 & 11.10 & Clay \\
\hline 5. & Changoubung & 5.00 & 22.00 & 0.09 & 208.70 & 31.30 & 128.20 & 1.70 & 1.90 & 67.30 & 14.60 & 18.10 & Clay \\
\hline 6. & Kangpokpi & 5.11 & 19.00 & 0.16 & 267.25 & 29.50 & 230.00 & 2.85 & 1.60 & 58.99 & 28.80 & 12.21 & Clay \\
\hline 7. & Daily village & 4.60 & 24.00 & 0.17 & 279.34 & 33.05 & 172.30 & 3.20 & 2.50 & 55.30 & 30.00 & 14.70 & Clay \\
\hline 8. & Yaikongpao & 5.14 & 23.00 & 0.11 & 412.42 & 55.95 & 209.50 & 1.80 & 0.70 & 56.30 & 33.50 & 10.20 & Clay \\
\hline 9. & Keithelmanbi & 5.05 & 18.50 & 0.15 & 339.07 & 54.00 & 191.70 & 2.50 & 0.80 & 40.10 & 28.60 & 31.30 & Clay loam \\
\hline 10. & Gopibung & 5.60 & 13.40 & 0.12 & 341.80 & 30.00 & 102.00 & 2.70 & 0.70 & 53.90 & 31.00 & 15.10 & Clay \\
\hline 11. & Sapormeina & 4.89 & 21.50 & 0.18 & 420.05 & 51.90 & 103.20 & 1.25 & 0.70 & 56.80 & 32.00 & 11.20 & Clay \\
\hline 12. & Koubruleikha & 5.16 & 16.70 & 0.12 & 352.52 & 35.45 & 171.50 & 2.20 & 1.40 & 37.90 & 33.50 & 28.60 & Clay loam \\
\hline 13. & Motbung & 4.99 & 24.00 & 0.12 & 346.60 & 40.10 & 185.40 & 2.65 & 0.35 & 59.82 & 22.20 & 17.98 & Clay \\
\hline 14. & Taphou Kuki & 5.62 & 16.10 & 0.11 & 228.50 & 22.80 & 92.10 & 3.80 & 2.40 & 47.07 & 32.93 & 20.00 & Clay \\
\hline 15. & Parengba & 5.22 & 22.10 & 0.14 & 359.00 & 28.25 & 150.00 & 3.90 & 1.30 & 56.90 & 34.00 & 9.10 & Clay \\
\hline 16. & Karong & 5.09 & 22.00 & 0.18 & 423.25 & 64.00 & 155.00 & 3.80 & 2.70 & 55.40 & 29.80 & 14.80 & Clay \\
\hline 17. & Katomei & 5.14 & 23.00 & 0.13 & 370.34 & 49.50 & 172.00 & 2.60 & 1.40 & 50.00 & 38.00 & 12.00 & Clay \\
\hline 18. & Senapati Bazar & 5.18 & 19.40 & 0.14 & 332.14 & 39.50 & 125.00 & 2.70 & 0.80 & 47.47 & 35.93 & 16.60 & Clay \\
\hline 19. & Makhan & 5.55 & 23.00 & 0.09 & 375.50 & 53.65 & 92.20 & 4.00 & 1.15 & 54.90 & 37.00 & 8.10 & Clay \\
\hline 20. & Purul & 5.60 & 17.00 & 0.18 & 328.06 & 19.90 & 119.20 & 2.50 & 0.80 & 42.80 & 25.90 & 31.30 & Clay loam \\
\hline \multicolumn{2}{|c|}{ Range value } & $4.50-5.62$ & $13.40-24.00$ & $\begin{array}{l}0.09- \\
0.22\end{array}$ & $\begin{array}{l}208.70-4 \\
23.25\end{array}$ & $18-64$ & $\begin{array}{l}90.34-243 . \\
10\end{array}$ & $1.25-4$ & $0.35-3.20$ & $\begin{array}{l}37.90- \\
67.30\end{array}$ & $\begin{array}{l}14.60- \\
40.10\end{array}$ & $\begin{array}{l}8.10 \text { - } 31 . \\
30\end{array}$ & \\
\hline \multicolumn{2}{|c|}{ Mean } & 5.15 & 20.35 & 0.14 & 335.14 & 39.40 & 151.90 & 2.74 & 1.43 & 53.21 & 30.82 & 15.92 & \\
\hline
\end{tabular}

Table.2 Amount of available soil P content extracted by various methods (ppm)

\begin{tabular}{|c|c|c|c|}
\hline Extractant & Range & Mean & References \\
\hline Bray and Kurtz No.1 $0.003 \mathrm{~N} \mathrm{NH}_{4} \mathrm{~F}+0.025 \mathrm{~N} \mathrm{HCl}$ & $7.54-28.90$ & 15.93 & Bray and Kurtz (1945) \\
\hline Bray No. $20.1 \mathrm{~N} \mathrm{HCl}+0.03 \mathrm{~N} \mathrm{NH}_{4} \mathrm{~F}$ & $15.44-50.06$ & 29.26 & Bray and Kurtz (1945) \\
\hline Mehlich1 $\left(0.0125 \mathrm{M} \mathrm{H}_{2} \mathrm{SO}_{4}+0.05 \mathrm{M} \mathrm{HCl}\right)$ & $7.50-25.00$ & 13.49 & Nelson et al., (1953) \\
\hline Mehlich3 0.2M CH $3 \mathrm{COOH}_{0} 0.25 \mathrm{M} \mathrm{NH}_{4}$ & $8.22-25.00$ & 16.29 & Mehlich (1984) \\
\hline Olsen $\mathrm{P}\left(0.5 \mathrm{M} \mathrm{NaHCO}_{3}\right), \mathrm{pH}-8.5$ & $6.00-22.00$ & 14.34 & Olsen et al., (1954) \\
\hline Troug $\left(0.002 \mathrm{NH}_{2} \mathrm{SO}_{4}, \mathrm{pH}-3\right)$ & $11.11-41.00$ & 23.67 & Troug \\
\hline
\end{tabular}


Table.3 Effect of phosphorus application on dry matter yield, phosphorus concentration and its uptake by pea crop

\begin{tabular}{|c|c|c|c|c|c|c|c|c|c|c|c|}
\hline \multirow{3}{*}{$\begin{array}{l}\text { Soil } \\
\text { No. }\end{array}$} & \multirow[t]{3}{*}{ Bray 1} & \multirow{2}{*}{\multicolumn{3}{|c|}{$\begin{array}{c}\text { Dry matter yield (g/pot) } \\
\text { P }_{2} \mathrm{O}_{5} \text { level }\left(\mathrm{kg} \mathrm{ha}^{-1}\right)\end{array}$}} & \multirow[t]{3}{*}{ Mean } & \multirow{3}{*}{$\begin{array}{c}\text { Bray's \% } \\
\text { yield }\end{array}$} & \multirow{3}{*}{$\begin{array}{l}\text { P concentration in } \\
\text { plants of no P pots } \\
(\%)\end{array}$} & \multirow{2}{*}{\multicolumn{3}{|c|}{$\begin{array}{c}\text { P Uptake by plants (mg/pot) } \\
\mathbf{P}_{2} \mathrm{O}_{5} \text { level }\left(\mathrm{kg} \mathrm{ha}^{-1}\right)\end{array}$}} & \multirow{3}{*}{$\begin{array}{c}\text { Bray's \% P } \\
\text { Uptake }\end{array}$} \\
\hline & & & & & & & & & & & \\
\hline & & 0 & 40 & 60 & & & & 0 & 40 & 60 & \\
\hline 1 & 18.18 & 2.53 & 2.67 & 3.86 & 3.02 & 65.54 & 0.35 & 10.40 & 11.48 & 18.91 & 54.99 \\
\hline 2 & 14.90 & 1.7 & 2.65 & 2.62 & 2.32 & 64.15 & 0.48 & 7.50 & 18.55 & 19.39 & 38.68 \\
\hline 3 & 22.56 & 2.72 & 2.98 & 2.99 & 2.90 & 90.97 & 0.43 & 10.61 & 13.41 & 15.25 & 69.58 \\
\hline 4 & 10.05 & 1.33 & 2.06 & 2.59 & 1.99 & 51.35 & 0.4 & 5.32 & 8.86 & 13.47 & 39.50 \\
\hline 5 & 16.31 & 2.54 & 2.79 & 3.86 & 3.06 & 65.8 & 0.42 & 10.70 & 12.83 & 19.30 & 55.44 \\
\hline 6 & 24.67 & 2.89 & 2.84 & 2.9 & 2.88 & 97.93 & 0.53 & 14.20 & 15.62 & 21.17 & 67.08 \\
\hline 7 & 21.00 & 1.72 & 2.81 & 2.83 & 2.45 & 92.58 & 0.63 & 14.11 & 17.98 & 20.38 & 69.25 \\
\hline 8 & 18.22 & 2.56 & 2.68 & 4.19 & 3.14 & 60.78 & 0.41 & 10.50 & 11.79 & 20.95 & 50.12 \\
\hline 9 & 11.40 & 1.43 & 2.91 & 3 & 2.45 & 47.67 & 0.47 & 7.80 & 15.13 & 16.20 & 48.15 \\
\hline 10 & 13.43 & 1.37 & 2.75 & 2.84 & 2.32 & 48.24 & 0.29 & 3.42 & 8.25 & 17.61 & 19.42 \\
\hline 11 & 12.00 & 2.51 & 2.57 & 4.32 & 3.13 & 58.1 & 0.38 & 7.00 & 12.59 & 20.74 & 33.76 \\
\hline 12 & 19.17 & 1.31 & 2.8 & 2.82 & 2.31 & 46.45 & 0.42 & 7.50 & 13.44 & 16.64 & 45.08 \\
\hline 13 & 16.22 & 2.12 & 2.7 & 2.8 & 2.54 & 75.71 & 0.42 & 14.00 & 15.39 & 21.00 & 66.67 \\
\hline 14 & 12.65 & 1.8 & 2.56 & 4.35 & 2.90 & 41.38 & 0.39 & 9.50 & 12.29 & 20.01 & 47.48 \\
\hline 15 & 18.00 & 1.08 & 3.01 & 2.95 & 2.35 & 35.88 & 0.36 & 4.00 & 15.05 & 15.34 & 26.08 \\
\hline 16 & 11.00 & 1.51 & 3.55 & 3.05 & 2.70 & 42.53 & 0.4 & 6.02 & 14.56 & 19.83 & 30.37 \\
\hline 17 & 28.90 & 2.81 & 2.85 & 2.32 & 2.66 & 81.4 & 0.51 & 16.30 & 19.10 & 16.70 & 85.36 \\
\hline 18 & 9.08 & 1.35 & 2.09 & 2.59 & 2.01 & 52.12 & 0.37 & 4.40 & 9.20 & 15.80 & 27.85 \\
\hline 19 & 13.32 & 2 & 2.77 & 2.85 & 2.54 & 70.17 & 0.41 & 8.10 & 15.24 & 22.80 & 35.53 \\
\hline 20 & 7.54 & 1.29 & 1.86 & 2.78 & 1.98 & 46.4 & 0.4 & 4.42 & 8.18 & 13.07 & 33.83 \\
\hline Mean & 15.93 & 1.93 & 2.70 & 3.13 & 2.58 & 61.1 & 0.42 & 8.79 & 13.45 & 18.23 & 47.21 \\
\hline
\end{tabular}


Table.4 Effect of phosphorus application on nitrogen, phosphorus and potassium uptake in pea crop

\begin{tabular}{|c|c|c|c|c|c|c|c|c|c|c|c|c|c|}
\hline \multirow[t]{3}{*}{ Soil No. } & \multirow[t]{3}{*}{ Bray 1} & \multicolumn{4}{|c|}{$\mathrm{N}$ uptake in plants (mg/pot) } & \multicolumn{4}{|c|}{ P uptake in plants (mg/pot) } & \multicolumn{4}{|c|}{ K uptake in plants (mg/pot) } \\
\hline & & \multicolumn{4}{|c|}{$\mathrm{P}_{2} \mathrm{O}_{5}$ level $\left(\mathrm{kg} \mathrm{ha}^{-1}\right)$} & \multicolumn{4}{|c|}{$\mathrm{P}_{2} \mathrm{O}_{5}$ level $\left(\mathrm{kg} \mathrm{ha}^{-1}\right)$} & \multicolumn{4}{|c|}{$\mathrm{P}_{2} \mathrm{O}_{5}$ level $\left(\mathrm{kg} \mathrm{ha}^{-1}\right)$} \\
\hline & & $\mathbf{0}$ & 40 & 60 & Mean & $\mathbf{0}$ & 40 & 60 & Mean & $\mathbf{0}$ & 40 & 60 & Mean \\
\hline 1 & 18.18 & 26.57 & 30.97 & 48.25 & 35.26 & 10.40 & 11.48 & 18.91 & 13.60 & 27.83 & 30.17 & 49.41 & 35.80 \\
\hline 2 & 14.90 & 15.30 & 26.50 & 32.23 & 24.68 & 7.50 & 18.55 & 19.39 & 15.15 & 16.15 & 26.77 & 30.13 & 24.35 \\
\hline 3 & 22.56 & 25.30 & 35.76 & 37.38 & 32.81 & 10.61 & 13.41 & 15.25 & 13.09 & 24.21 & 29.50 & 36.18 & 29.96 \\
\hline 4 & 10.05 & 11.70 & 21.63 & 32.63 & 21.99 & 5.32 & 8.86 & 13.47 & 9.22 & 10.11 & 17.10 & 23.57 & 16.93 \\
\hline 5 & 16.31 & 26.67 & 32.09 & 49.02 & 35.93 & 10.70 & 12.83 & 19.30 & 14.28 & 21.84 & 30.41 & 50.95 & 34.40 \\
\hline 6 & 24.67 & 26.88 & 31.24 & 35.67 & 31.26 & 14.20 & 15.62 & 21.17 & 17.00 & 25.43 & 27.26 & 31.61 & 28.10 \\
\hline 7 & 21.00 & 16.51 & 28.38 & 35.09 & 26.66 & 14.11 & 17.98 & 20.38 & 17.49 & 14.62 & 25.29 & 30.85 & 23.59 \\
\hline 8 & 18.22 & 27.39 & 32.16 & 55.73 & 38.43 & 10.50 & 11.79 & 20.95 & 14.41 & 26.88 & 29.75 & 51.96 & 36.19 \\
\hline 9 & 11.40 & 12.87 & 29.10 & 37.50 & 26.49 & 7.80 & 15.13 & 16.20 & 13.04 & 11.73 & 36.08 & 41.10 & 29.64 \\
\hline 10 & 13.43 & 13.15 & 29.43 & 33.51 & 25.36 & 3.42 & 8.25 & 17.61 & 9.76 & 10.55 & 22.83 & 25.84 & 19.74 \\
\hline 11 & 12.00 & 26.10 & 32.13 & 56.16 & 38.13 & 7.00 & 12.59 & 20.74 & 13.44 & 25.10 & 32.38 & 50.98 & 36.15 \\
\hline 12 & 19.17 & 11.27 & 28.84 & 34.12 & 24.74 & 7.50 & 13.44 & 16.64 & 12.53 & 13.36 & 32.76 & 35.25 & 27.12 \\
\hline 13 & 16.22 & 20.35 & 27.81 & 34.44 & 27.53 & 14.00 & 15.39 & 21.00 & 16.80 & 19.08 & 26.73 & 35.00 & 26.94 \\
\hline 14 & 12.65 & 18.36 & 29.95 & 58.29 & 35.53 & 9.50 & 12.29 & 20.01 & 13.93 & 19.08 & 29.44 & 50.46 & 32.99 \\
\hline 15 & 18.00 & 11.45 & 37.93 & 30.09 & 26.49 & 4.00 & 15.05 & 15.34 & 11.46 & 8.75 & 36.12 & 31.57 & 25.48 \\
\hline 16 & 11.00 & 15.86 & 45.09 & 40.87 & 33.94 & 6.02 & 14.56 & 19.83 & 13.47 & 13.14 & 33.73 & 32.94 & 26.60 \\
\hline 17 & 28.90 & 28.10 & 30.78 & 31.32 & 30.07 & 16.30 & 19.10 & 16.70 & 17.37 & 25.01 & 27.08 & 26.91 & 26.33 \\
\hline 18 & 9.08 & 12.02 & 22.78 & 33.41 & 22.74 & 4.40 & 9.20 & 15.80 & 9.80 & 16.34 & 26.75 & 32.89 & 25.33 \\
\hline 19 & 13.32 & 19.40 & 30.47 & 33.92 & 27.93 & 8.10 & 15.24 & 22.80 & 15.38 & 16.60 & 33.24 & 30.78 & 26.87 \\
\hline 20 & 7.54 & 12.26 & 20.46 & 31.97 & 21.56 & 4.42 & 8.18 & 13.07 & 8.56 & 7.48 & 16.00 & 26.41 & 16.63 \\
\hline Mean & 15.93 & 18.87 & 30.17 & 39.08 & & 8.79 & 13.45 & 18.23 & & 17.66 & 28.47 & 36.24 & \\
\hline
\end{tabular}


Table.5 Simple correlation co-efficient between the different forms of phosphorus and yield parameters of pea

\begin{tabular}{|c|c|c|c|c|c|}
\hline No. & Extractant & $\begin{array}{l}\text { Dry matter yield } \\
\text { (Control) }\end{array}$ & P uptake (Control) & Bray's \% Yield & $\begin{array}{c}\text { Bray's } \\
\text { \%Uptake }\end{array}$ \\
\hline 1 & Bray 1 & $0.636^{* *}$ & $0.773^{* *}$ & $0.699 * *$ & $0.783 * *$ \\
\hline 2 & Bray 2 & $0.463 *$ & $0.535^{*}$ & $0.480 *$ & $0.517 *$ \\
\hline 3 & Mehlich 1 & -0.319 & -0.326 & -0.091 & -0.301 \\
\hline 4 & Mehlich 3 & $0.493^{*}$ & $0.509^{*}$ & $0.469^{*}$ & $0.578^{* *}$ \\
\hline 5 & Troug & $0.475^{*}$ & 0.310 & $0.518^{*}$ & 0.308 \\
\hline 6 & Olsen & -0.322 & -0.141 & -0.136 & -0.004 \\
\hline 7 & Saloid-P & -0.217 & 0.099 & 0.009 & 0.04 \\
\hline 8 & Iron-P & 0.205 & 0.101 & 0.315 & 0.113 \\
\hline 9 & Aluminium-P & 0.410 & $0.575^{* *}$ & $0.471 *$ & $0.616^{* *}$ \\
\hline 10 & Reductant-soluble-P & 0.361 & 0.33 & 0.406 & $0.465^{*}$ \\
\hline 11 & Occluded-P & -0.179 & 0.061 & 0.06 & 0.214 \\
\hline 12 & Calcium-P & -0.005 & 0.046 & 0.002 & 0.060 \\
\hline 13 & Organic-P & -0.366 & -0.011 & 0.079 & -0.052 \\
\hline 14 & Total-P & -0.096 & 0.169 & 0.274 & 0.191 \\
\hline
\end{tabular}

Fig.1 Relationship between Bray 1 and Bray’s percent yield

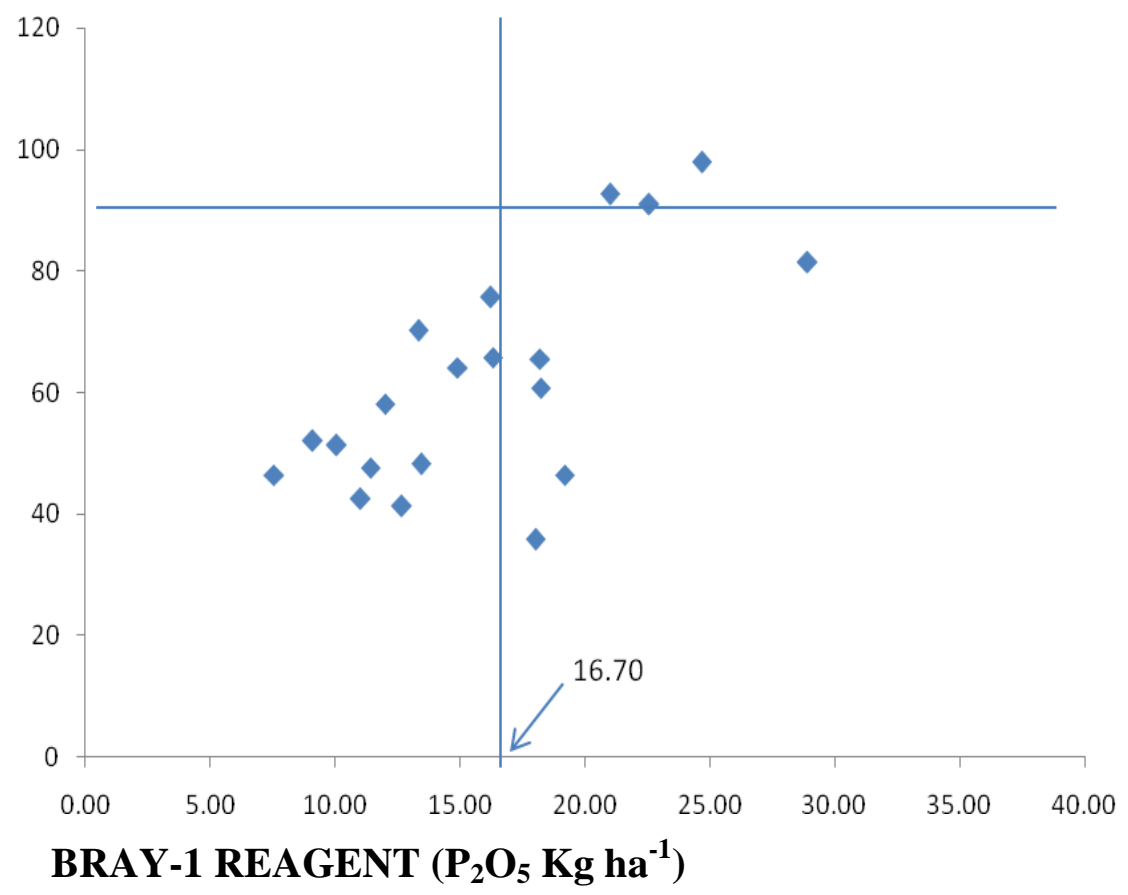


Fig.2 Relationship between Bray 2 and Bray’s percent yield

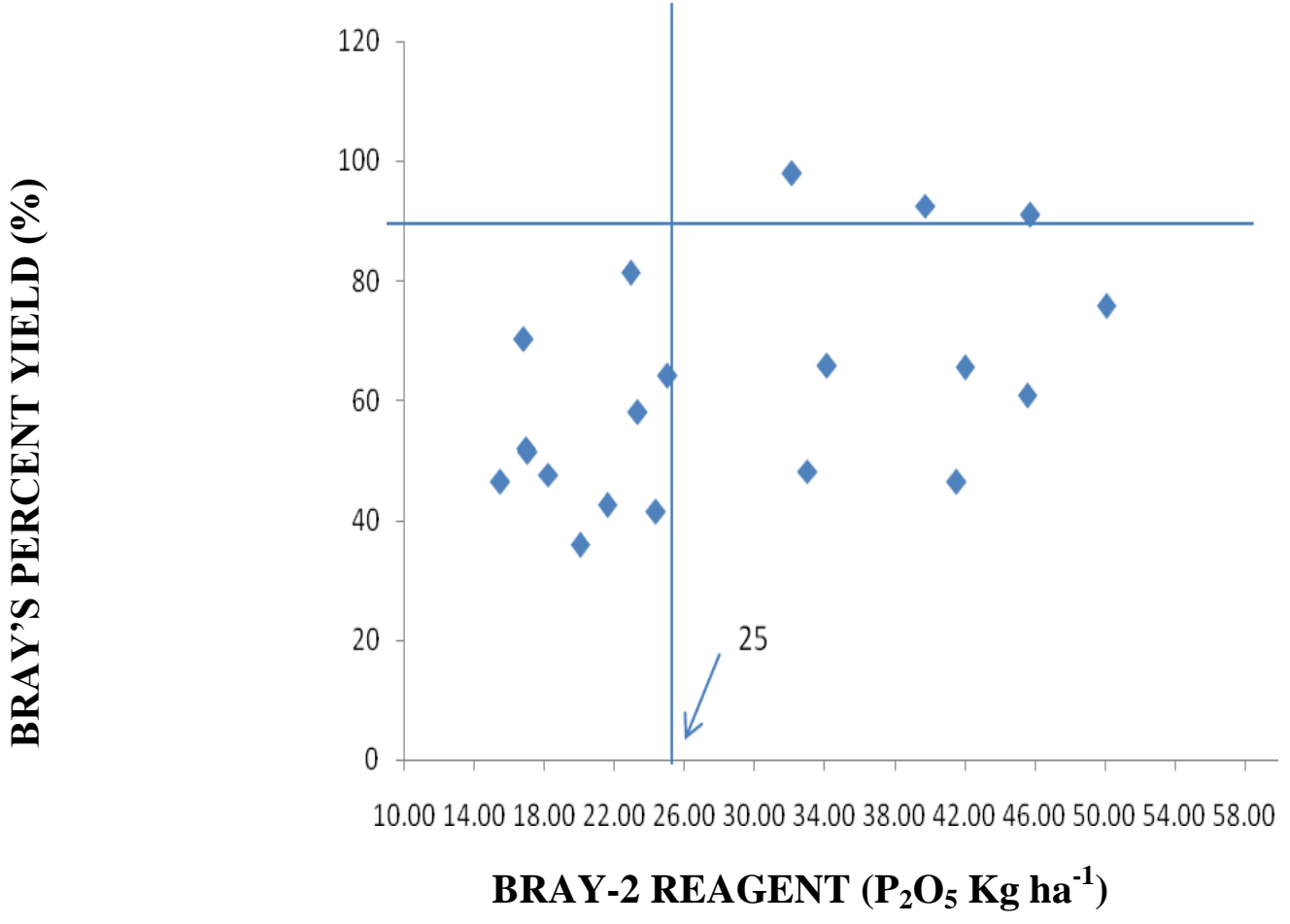

Fig.3 Relationship between Mehlich 3 and Bray's percent yield

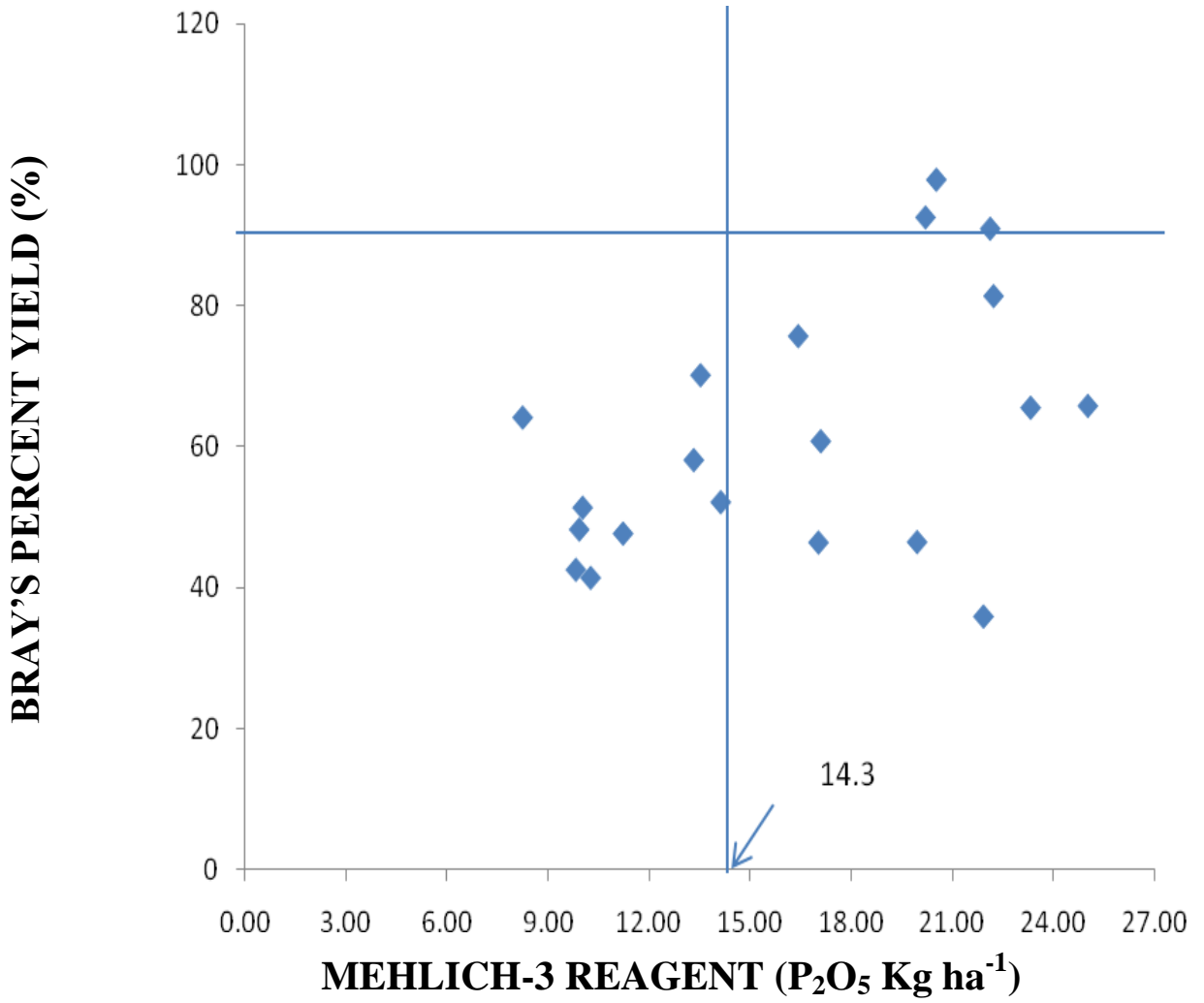


Fig.4 Relationship between Troug and Bray's percent yield

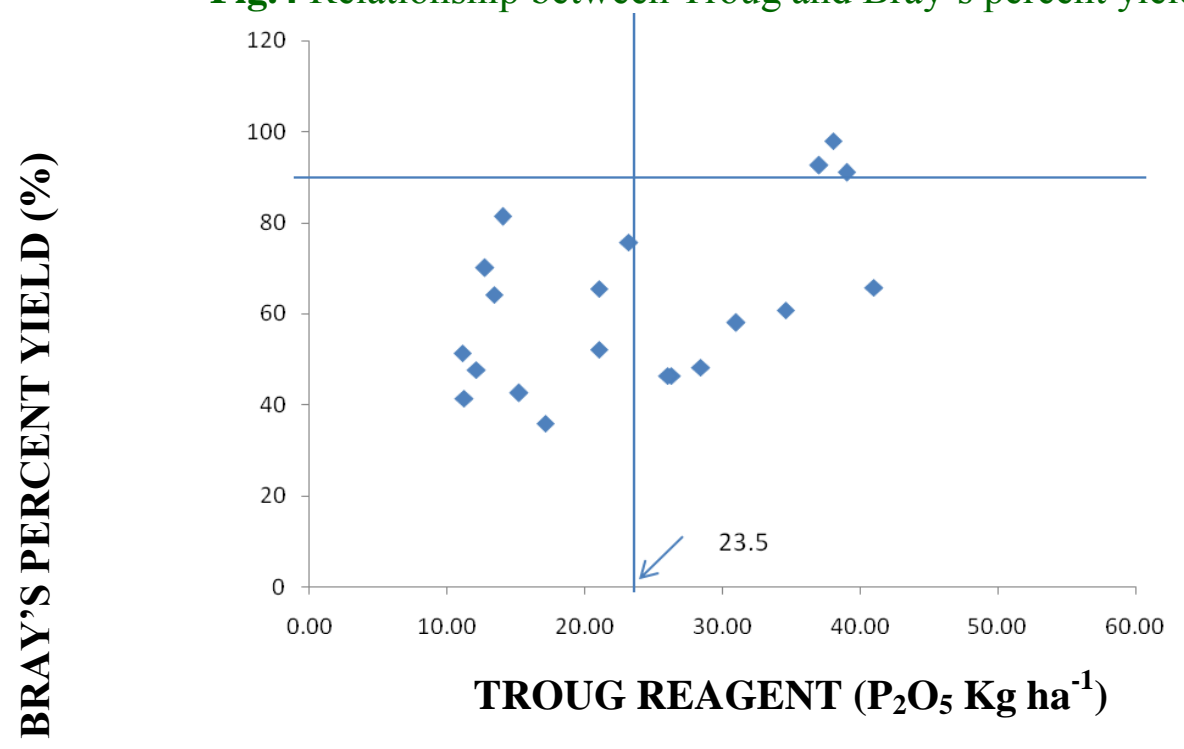

Fig.5 Relationship between phosphorus concentration and Bray's percent yield

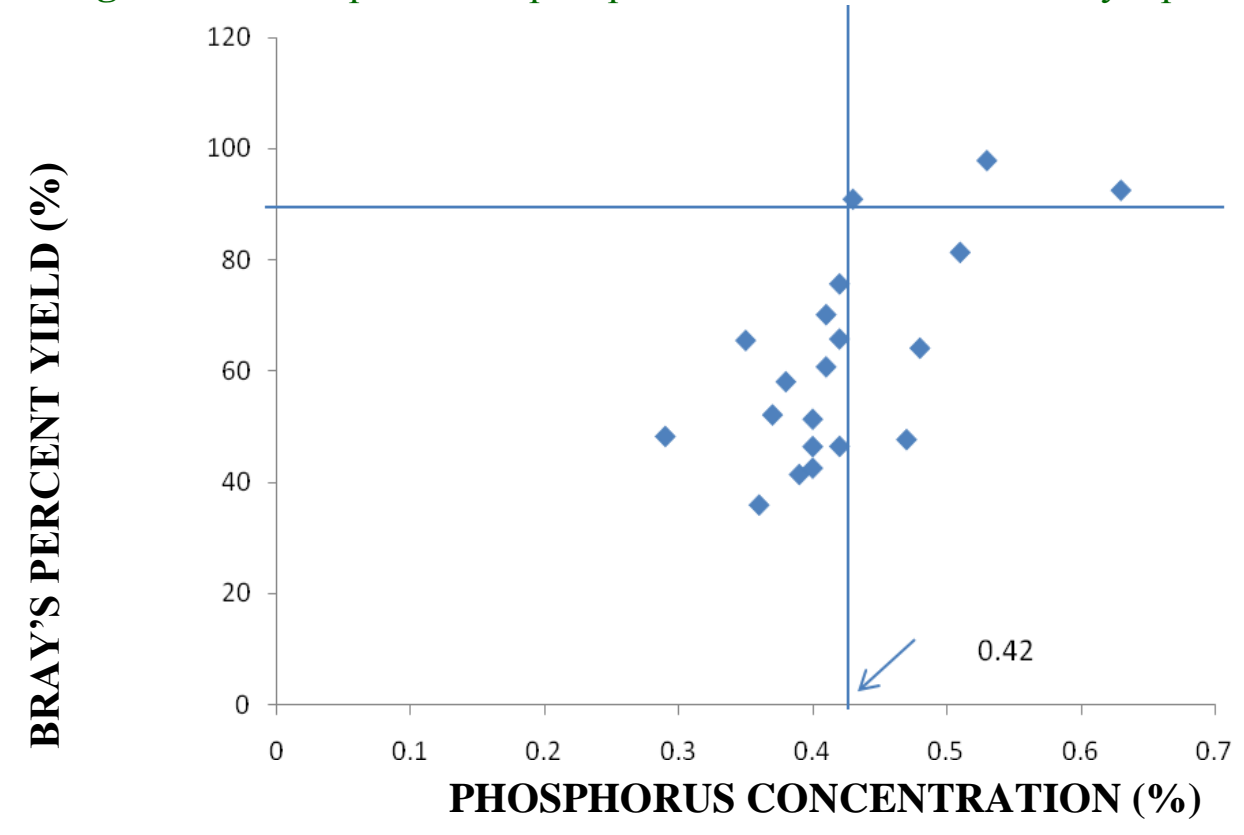

Plant

The result revealed that the critical level of the phosphorus concentration in the pea was found 0.42 per cent (Fig. 5) according to graphical procedure of Cate and Nelson (1965) using a scatter diagram (Fig. 2), partitioning the two dimensional percentage yield versus phosphorus content in the 40 days old pea plants (control) scattered into two groups (Fig. 3 and 4).

From the above findings, it can be concluded that the method employed for extraction of soil Phosphorous was negatively and significantly correlated with $\mathrm{pH}$, except 
Olsen. Troug was positively and significantly correlated with silt and clay. Among the various extractants used for phosphorus extraction, Bray 2 extracted highest amount of phosphorus from soils. However, Bray 1 extractant found highest and significantly correlated with Bray's per cent yield and uptake. Accordingly, Bray 1 reagent can be used as estimating phosphorus contents of the soils for pea growing. All the studied soils below $16.70 \mathrm{~kg} \mathrm{P}_{2} \mathrm{O}_{5} \mathrm{ha}^{-1}$ may respond to phosphorus application. The critical level of the soils varies from different extractants used for estimation of phosphorus.

From the pot culture studies, it was observed that for estimating the critical plant tissue concentration of phosphorus in pea, a value of 0.42 per cent was the critical level. A value of 0.42 per cent plant tissue phosphorus concentration could distinguish the phosphorus deficient plants. Thus, the present study lays emphasis on phosphorus fertilization of pea plant on the basis of critical values in soil and plant. Therefore, the farmers growing pea crops should fertilized based on the critical limit of both soil and plant.

\section{References}

Anonymous. 2009. Baseline Survey of Minority Concentrated Districts. District Report Senapati. Study Commissioned by Ministry of Minority Affairs Government of India. P. 14.

Attar, H.A. 2014. Phosphorus Availability and Proton Efflux of Nodulated-root Varies among Common-bean Genotypes (Phaseolus vulgaris) in Rhizobox. Inter $J$ Agri Environ Biotechnol 7(2): 391-402.

Bhalu VB, Sadaria SG, Kaneria BB, khanpara VD (1995) Effect of nitrogen, phosphorus and Rhizobium inoculation on yield and quality, $\mathrm{N}$ and $\mathrm{P}$ uptake and economics of blackgram. IndianJ Agron 40 (2): 316-318.

Bhat TA, Gupta M, Ganai MA, Ahanger RA and Bhat HA (2013) Yield, soil health and nutrient utilization of field pea (Pisum sativum L.) as affected by phosphorus and Biofertilizers under subtropical conditions of Jammu, International journal of modern plant and animal science, 1(1):1-8.

Bhattacharyya P.N., Jha D.K. 2012. Plant growthpromoting rhizobacteria (PGPR): emergence in agriculture. World Journal of Microbiology and Biotechnology, 28:1327-1350, doi: 10.1007/s11274011-0979-9

Bray, R.H., Kurtz, L.T., 1945. Determination of total organic and available forms of phosphate in soils. Soil Sci. 59: 39- 45. http://dx.doi.org/10.1097/00010694-194 501000-00006

Cate, R.B. and Nelson, L.A., 1965. A rapid method for correlation of soil test analysis with plant response data. International Soil Test Series Technology Bulletin. No.1.North Carolina State University Agricultural Experiment Station, Raleigh.

Das, A., Ramkrushna, G.I., Makdoh, B., Sarkar, D., Layek, J., Mandal, S. and Lal, R., 2016. Managing Soils of the Lower Himalayas. Encyclopedia of Soil Science, Third Edition DOI: 10.1081/EESS3-120053284

Hussain N, Mehdi M, Kant RH (2001) Response of nitrogen and phosphorus on growth and tield attributes of Blackgram (Vigna mungo). Research Journal of Agricultural Sciences 2 (2): 334-336

Mehlich, A. 1984. Mehlich 3 Soil Test Extractants: A Modification of Mehlich 2 Extractant. Communications in Soil Science and Plant Analysis 15: 14091415. http:// dx.doi.org/10.1080/00 103628409367568 
Nelson, W.L., Mehlich, A., Winters, E. 1953. The development, evaluation and use of soil tests for phosphorus availability. Agronomy 4: 153-158

Olsen, S.R., Cole, C.V., Watanabe, F.S., Dean, L.A. 1954. Estimation of available phosphorus in soils by extraction with sodium bicarbonate. Circ. No.939 US Dept. Agri. Washington, DC P.19.

Pulung, M.A. 1994. Effect of fertilizer rates on yield, productive efficiency of pea on brown podzolic soil. Acta. Hort., 369: 306-310.
Reddy TR, Rao M, Rao KR (1990) Response of soybean (Glycine max (L.) Merrill to nitrogen and phosphorus. Journal of Indian Society of Soil science 35 (3): \#08- 310

Slinkard, A.E. and Drew, B.N. 1998. Dry pea production in Saskatchewan Ag. Dex. 140:10 (Rev). Univ. Saskatchewan, pp.7. Saskatoon

Troug, E. 1930. The determination of readily available phosphorus of soils $\mathrm{J}$ Amer Soc Agron 22: 274

\section{How to cite this article:}

Haribhushan Athokpam, Goutam Kumar Ghosh, Herojit Singh Athokpam, N. Anando Singh, Kangjam Sonamani Singh, Khamrang Mathukmi, R. S. Telem, Romila Akoijam, Shabir Hussain Wani, Nandini Chongtham and Naorem Brajendra Singh. 2018. Critical Limits of Phosphorus in Soil and Pea Plant Grown in Acid Soils of Senapati District of Manipur, India. Int.J.Curr.Microbiol.App.Sci. 7(09): 3106-3118. doi: https://doi.org/10.20546/ijcmas.2018.709.387 